\title{
Efficiency of Tabarru' Fund Management at Islamic insurance Companies in Indonesia
}

\section{Marina Sarah, A. Jajang W. Mahri, and Aneu Cakhyaneu}

Economics and Islamic Finance Department, Universitas Pendidikan Indonesia, JI. Dr. Setiabudhi No. 229, Kota Bandung, Indonesia

\section{Abstract}

The growth of Islamic insurance has been quite rapid in recent years, but in 2013 the performance was less than optimal. There are only six life insurance that have received surplus and seven general insurance that still deficit. One of many causes of the lack of optimal performance is inefficiency, while that is related to how to obtain the maximum level of output with a certain amount of input. This study aims to determine level of efficiency in Islamic insurance for the period 2012-2016 and find out the causes. This study uses secondary data from 13 companies. Research method used is descriptive with Data Envelopment Analysis (DEA). The input variables used assets, operating

Corresponding Author:

Marina Sarah

marinasarah@student.upi.edu

Received: 10 February 2019

Accepted: 14 March 2019

Published: 28 March 2019

Publishing services provided by Knowledge E

(c) Marina Sarah et al. This article is distributed under the terms of the Creative Commons

Attribution License, which permits unrestricted use and redistribution provided that the original author and source are credited.

Selection and Peer-review under the responsibility of the ICIEBP Conference Committee. expenses and claim payments. Furthermore, output variables used contributions, investment income and tabarru' funds. Based the results of research conducted is known that, the condition of Islamic insurance in Indonesia hasn't been efficient. There were 12 companies that experienced inefficiencies due to the high operational costs and the low contribution.

Keywords: Efficiency, Islamic Insurance Companies, Data Envelopment Analysis (DEA).

\section{Introduction}

Islamic insurance is one of the Non-Bank Financial Institutions which is welcomed by various groups in Indonesia. Recorded in 2016 the number of Islamic insurance was only 11 Units and 47 Sharia Business Unit Companies, while in 2017 the number of Islamic insurance reached 13 Units and 50 Sharia Business Unit Companies (OJK, 2017). At another research by Sherif (2013), the development of Islamic banking institutions and the number of Muslim populations have a positive impact on the amount of Islamic insurance demand in Malaysia. This shows that the popularity of Islamic insurance is quite comprehensive in various regions.

The opening of a branch or business unit of the company is a necessity, it is an operational support in order to expand the target market. Islamic insurance Law is currently still being debated, but in Indonesia through the National Sharia Board has 
issued several policy including No: 21 / DSN-MUI / X / 2001, No: 53 / DSN-MUI / III / 2006 and No: 52 / DSN-MUI / III / 2006, so Islamic insurance products still have the opportunity to continue to grow and move optimistically (Maksum, 2011).

According to Kurnia (2015), in the 2015 Islamic Finance Outlook, stated that the performance of Islamic insurance companies in managing tabarru' funds in 2013 was still less than optimal. It is known that there are only six life insurance companies that achieved a surplus in that year, while in general insurance there were still seven companies that experienced a deficit in the same year. Similar research shows that the Conventional Insurance and Islamic insurance industries in Bangladesh, when the size of the company smaller, then the possibility for the company to be more efficient in utilizing inputs to produce more output will be higher (Rahman, 2013).

Based on news reported in Wilko (2017) it is known that PT. Takaful General closes due to two things, namely the number of non-developing company contributions and the risk best capital. This resulted in the company's performance being poor, so the company had to prepare strategic steps so that the company would survive. When referring to the data, the ability of the Islamic Insurance company to manage finances is not optimal. So that efficiency is one of the problems that can occur in this case, but to find out the accuracy of these data, further research is needed by using appropriate measurement and analysis tools.

Efficiency is a comparison between the output produced and the input used. A company or organization can be said to be efficient if it produces greater output using certain inputs (Farrell, 1957). According to Yahya bin Adam in his work, the Book of Al-Kharaj states that planning is one of the main functions of production management (Juliana, Firmansyah, \& Pratama, 2016).

Measurement of efficiency will help us understand and evaluate the performance and competitiveness of the industry to survive and develop in the future. The efficiency measurement can be carried out in two ways, namely input and output (Shafique, 2015). Shafique (2015) mentions that the director's skills and experience can provide positive results for the company by allocating optimal resources.

Based on research conducted by Saad (2011), Khan (2014), Tufahati \& Suprapto (2016), Benarda (2016) and Sabiti (2017), shows that Islamic insurance companies in some regions have not been able to achieve efficiency in various periods, while the measurement tool used to determine the level of efficiency is Data Envelopment Analysis (DEA). The purpose of this approach is to measure the relative efficiency of each DMU (Decision Making Unit) with best practice companies, the main advantage of this approach is lower demand of data so the sample size is smaller (Khan, 2014). 
Efficiency analysis of the Non-Bank Financial Institution industry is very important, given the very tight competition between institutions. One of them is by measuring the level of financial efficiency of Islamic Insurance companies because of its significant growth but still unable to compete with the banking industry. This analysis can be done in several Islamic Insurance companies in Indonesia as a medium to compare the performance between companies in a more specific scope. This comparison will be very beneficial for several parties, including the company and society in general. Based on the problems described above, the compiler feels the need to conduct research on, "Efficiency of Tabarru Fund Management at Islamic Insurance Companies in Indonesia".

\section{Literature Review}

There are several ways to measure the performance of a Islamic insurance company and one of them is by looking at the efficiency of each company (Abduh, 2012). Economic efficiency is stated if the input used can maximize output (Tasman \& Aima, 2013). As for the factors that cause efficiency, namely (1) If with the same input can produce greater output, (2) with smaller inputs producing the same output, (3) with larger inputs can produce more output with more presentations.

Leibenstein (1966) said, that the company operates at a less efficient level due to two things, namely: (1) failure to use resources efficiently or inefficiency in use; and (2) the company's failure to combine these resources optimally (Hidayat, 2014). According to Al-Amri (2015) Efficiency assessment can be seen from three types, namely: (1) Tecnical Efficiency, (2) Allocative Efficiency, (3) Cost Efficiency.

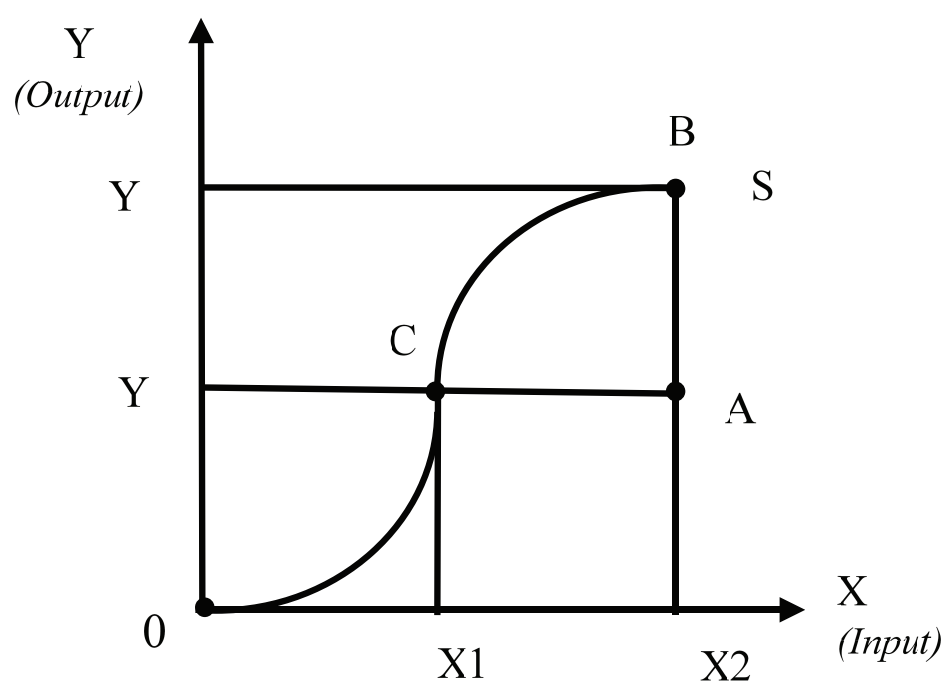

Figure 1: Concept of efficiency (Source: Hidayat (2014)). 
In Islam, efficient means to use something in moderation, not excessive and not lacking. As described in QS. Al-An'am: 141 as follows:

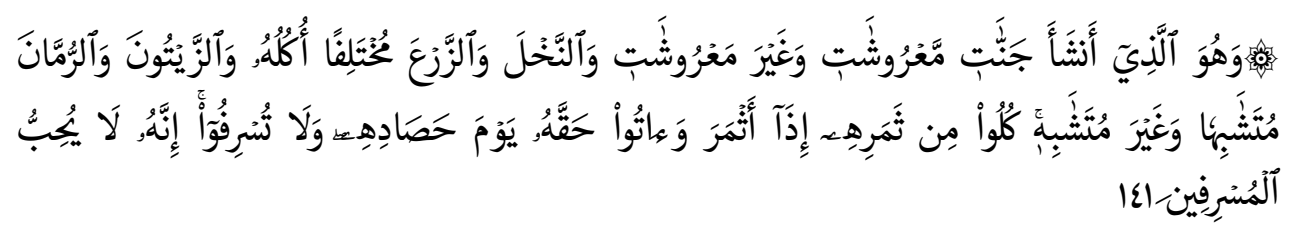

"And $\mathrm{He}$ is the one who makes upholding and unreserved gardens, palm trees, various kinds of plants, olives and pomegranates which are similar (their shape and color) and not the same (taste). Eat from the fruit (which is various) if he is fruitful, and fulfill his rights in the day to reap the rewards (by giving to the poor); and do not overdo it. Surely Allah does not like the overprivileged."

The Takaful Islamic insurance System is basically an Islamic-based protection system. Complementing the ban on riba, maisyir and gharar is a sharia-based element that is unique in economic transactions including Ta'awun (mutual help), Tabarru'at (willing to give up individual rights for contributions paid for collective benefits) and Mudharabah (for profit sharing) or Wakalah bil ujrah (Nahar, 2015). Islamic jurists (Islamic scholars) argue that the operation and structure of conventional insurance, in its current form, is not in accordance with Sharia rules and requirements because it embodies a number of misunderstandings in contracts and operations (Sherif \& Shaairi, 2013).

Fund Management is a way of working for an insurance company in handling premium funds that have been collected by investing it in other financial institutions as a stock of compensation payments (Berlian, 2017). There are two possibilities in managing insurance funds, the first is a surplus underwriting and the second is an deficit underwriting (Faozi, 2016). Defisit underwriting is a condition where the amount of expenses that must be incurred is higher than the amount of income earned, so the insurer must issue funds from qardh reserves.

Researches on Tabarru' Fund Management Efficiency have been widely carried out, both domestically and abroad. The conclusions are different. This difference occurs because it uses different methods and research periods. The analytical tool that is mostly used by researchers to measure the level of efficiency of Tabarru' Fund Management is Data Envelopment Analysis (DEA). The distinguishes previous research with this research is that it lies in the object under study, this research was conducted in Islamic Insurance companies listed on the OJK and published the annual report for the 20122016 period. 
Research conducted by Tufahatti (2016), about measuring the efficiency of Islamic insurance with the DEA method. The input variables are total assets and commission expenses and the output variables are gross contribution and investment income. As a result, Sharia Life Insurance and Sharia General Insurance have not been able to achieve optimal efficiency levels but the value of Sharia Life Insurance is more efficient. The causes of inefficiency are total assets, commission costs, gross contributions and investment income.

Benarda (2016), discuss the level of efficiency of the Sharia Life Insurance industry using a two stage approach with the Data Envelopment Analysis research method. By using Variable input (Assets, Expenses and Payment of claims) and its output (tabarru' funds and income). The results of this study indicate that the average is not yet efficient. Whereas in the second level analysis (Tobit Analysis) shows that the ratio of tabarru' funds solvency level has a positive and significant influence on technical efficiency and scale.

Sabiti (2017), discuss about the efficiency of Islamic insurance in Indonesia with DEA analysis method. The input variables are assets, expenses, claim payments and output variables, tabarru' income and funds. As a result Sharia Life Insurance and Sharia General Insurance have not reached the point of overall efficiency.

Other research carried out by Rahman (2013), which discuss about Comparative Study on the Efficiency of Bangladesh Conventional and Islamic Life Insurance Industry: A Non Parametric Approach. Input variables include commission expenses and management expenses, variable output of premium income and net income. The result is that Conventional Insurance is better than Islamic insurance. The smaller the size of the company, the greater the profitability and efficiency.

According to Khan (2014), which discuss about Efficiency Measure of Insurance vs Takaful Firms Using DEA Approach: A Case of Pakistan. The result is that overall Islamic insurance is not yet efficient. Output variables include asset investment, net premiums and input variables, labor, total fixed assets, business services, and capital investments. The results show that the insurance industry as a whole allocates inefficient costs. Islamic insurance companies are not more efficient than conventional insurance companies and there is no substantial technological contribution to increase overall productivity.

Faruk \& Rahman (2015), Life Insurance in Bangladesh is close to efficiency because improvements in technical changes in efficiency changes are contributed by pure efficiency and not scale efficiency is influenced by the size of the company. Efficiency research through ratio analysis shows that the average efficiency of Conventional 
Insurance companies is better. In the market Profitability of Islamic Insurance companies has not been able to compete (Janjua \& Akmal, 2015).

\section{Methodology}

The research method used in this study is a comparative descriptive method. This research will describe and measure the efficiency of Tabarru' fund management of Islamic insurance companies in Indonesia in the period 2012-2016. This efficiency analysis method requires data consisting of input and output of a DMU. Data collection techniques used are documentation techniques, gathering information derived from insurance financial reports. The tools used are Data Envelopment Analysis (DEA) with MaxDEA 6.1 software.

The DMU in this study are 13 companies and Islamic insurance business units, divided into 9 sharia life insurance and 4 Islamic general insurance companies in Indonesia. This research will use the intermediation approach. The input variables used are total assets, operating expenses and claim payments. The output variables used are payment of contributions, investments, and tabarru' funds. All data is sourced from financial statements that are time series. The DEA model used is the BCC-VRS model with the assumption that Islamic insurance does not work in optimal conditions.

\section{Result}

\subsection{Analysis factor of input and output}

The growth of Islamic insurance shows a fairly rapid development. These developments are supported by the inauguration of 50 business units and reinsurers companies up to 2017. The measurement of the development of Islamic insurance is not only seen from the company's growth, but can also be seen from the financial performance. The following is an explanation of the financial performance of Islamic insurance companies from 2012-2016. This explanation aims to see the development and compare the development of Islamic insurance in several years. 


\subsubsection{Total assets}

Overall the average total assets owned by PT. AIA Financial is the largest, reaching Rp. 7 trillion. Meanwhile, PT. Tokio Marine is a Islamic insurance company with the smallest average asset in the last five years, only Rp. 49 billion.

\subsubsection{Operational expenses}

PT. AlA Financial is a Islamic insurance company with the largest operating expenses reaching Rp. 462 billion. While PT. Panin Dai-Ichi Life is a company with the smallest amount of operational expenses of Rp. 4 billion. Each company has optimized the use of operational expenses, this can be seen from some of the decreases that have occurred in certain years.

\section{Payment of claims}

PT. Takaful families make the most claim payments. While PT. Tokio Marine becomes a company that pays a claim of at least Rp. 200 million over the past five years. All Islamic insurance companies have decreased insurance claim payments in various periods, except PT. Sunlife Financial, PT. Manulife Insurance and PT. AIA Financial, which has never experienced a decline in payment of Islamic insurance claims over the past five years.

\section{Payment of contributions}

Islamic insurance companies that obtain the highest total contribution is PT. AIA Financial is Rp. 705 billion. While the Islamic insurance company with the smallest contribution is PT. Tokio Merine as much as Rp. 1 billion. A company that is stable in obtaining contributions is PT. Sunlife Financial, PT. Askrida Insurance and PT. Manulife Insurance with a growing contribution rate every year.

\subsubsection{Investment}

Islamic insurance companies that obtain the largest investment income is PT. AlA Financial. Meanwhile, the Islamic insurance company that receives the smallest investment 


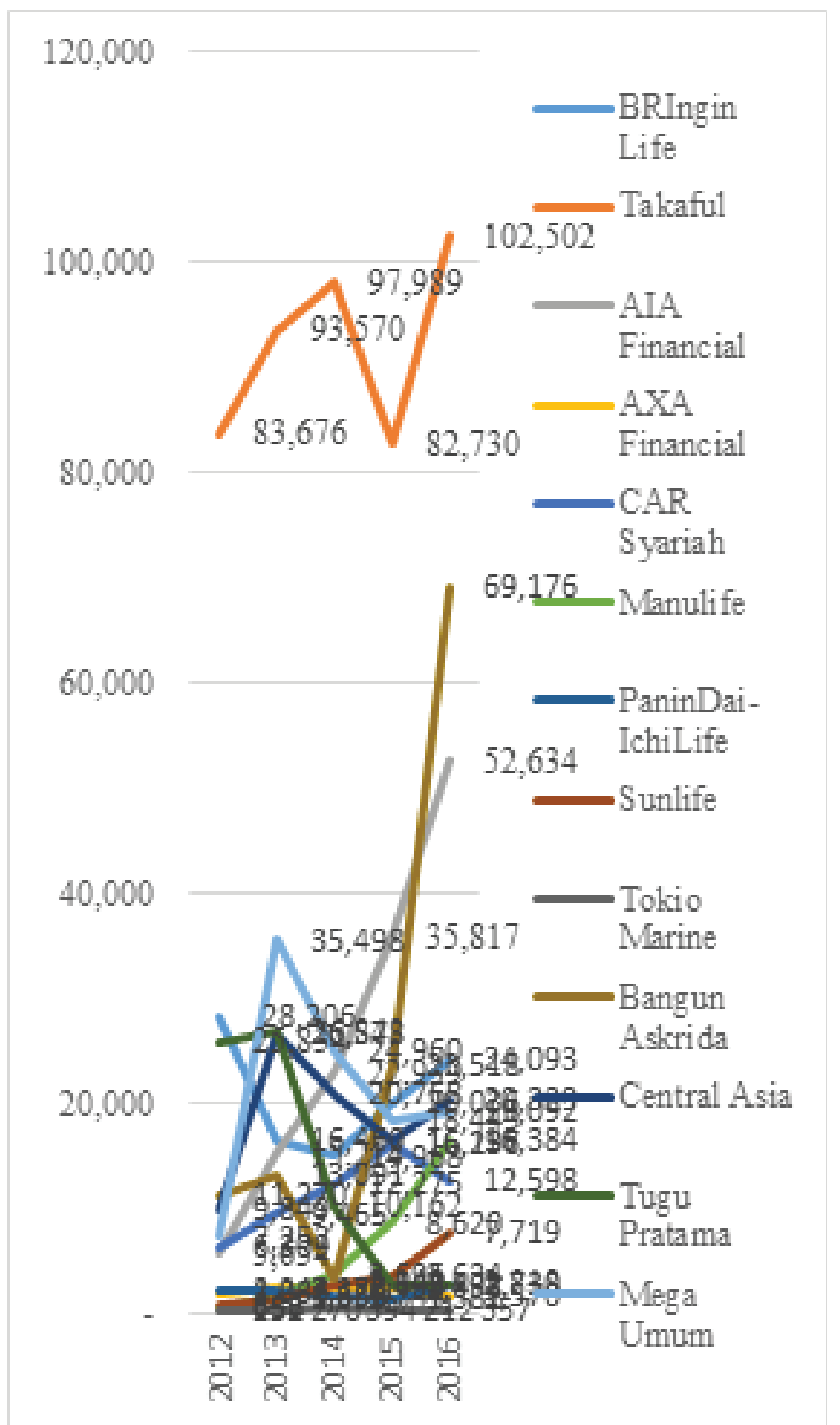

Figure 2: Growth of Payment for Islamic insurance Claims in 2012-2016 (Source: Financial reports of each Islamic insurance company (2012-2016)).

income is PT. Mega general because up to 2016 the amount of investment income has not been known. 


\subsubsection{Tabarru' fund}

The Islamic insurance Company that receives the biggest tabarru' fund is PT.AIA Financial. Then the Islamic insurance company that obtains the tabarru' fund is at least PT. Tugu Pratama Indonesia.

Based on the explanation above we can see that PT. AIA Financial is a company with rapid growth. Owning the largest assets, total contributions, tabarru' and investment income. But with a high insurance burden, it can be a reference for other Islamic insurance companies to continue to grow and develop. While there are several companies with growth that tend to be slow, namely companies with the smallest order. In general, we can see that PT. Tokio Marine is a company with the total assets, smallest claim payments and contributions. So that companies can continue to adapt all the needs in the Islamic insurance industry.

\subsection{Efficiency analysis of Islamic insurance companies}

Calculations using the DEA method assume that the company has been efficient with number 1 , while the company that has production inefficiency is assumed to obtain a value of 0 . The DEA method will provide information about the actual number, the number obtained in the current timeframe and the target number, which is expected to enable the company to reach the most efficient point. which is the result of calculating the level of efficiency of Islamic insurance companies for the period 2012-2016

Based on the results of the above research, it can be seen that the average value of the efficiency of the Islamic insurance company for the 2012-2016 period is still very low. It can be seen in Table 1 that the level of efficiency of Islamic insurance companies continues to fluctuate. Over the past five years, 2013 was the most crisis year for Islamic insurance companies in Indonesia. Of the 13 Islamic insurance companies studied during the 2012-2016 period, just in 2013 only six companies were found to reach an efficient point. While other companies namely PT. Askrida Insurance, PT. Sunlife Financial, PT. Tugu Pratama Indonesia, PT. Family Takaful, PT. Panin Dai-Ichi Life, PT. AXA Financial and PT. BRIngin Life has varied the level of efficiency.

The results also showed that 12 Islamic insurance companies experienced inefficiencies. These companies include PT. Askrida Insurance, PT. Sharia CAR, PT. Tokio Marine, PT. Tugu Pratama Indonesia, PT. Sunlife Financial, PT. Central Asia Insurance, PT. Takaful Family, PT. Panin Dai-Ichi Life, PT. Manulife Insurance, PT. Mega General Insurance, PT. BRIngin Life and PT. AXA Financial. Islamic insurance Company with the 
TABLE 1: The Efficiency Level of Islamic insurance Companies In 2012-2016.

\begin{tabular}{|c|c|c|c|c|c|c|}
\hline \multirow[t]{2}{*}{ NO } & \multirow[t]{2}{*}{ Name } & \multicolumn{5}{|c|}{ Year (2012-2016) } \\
\hline & & 1 & 2 & 3 & 4 & 5 \\
\hline 1 & TM & 0,9 & 1 & 1 & 1 & 0,8 \\
\hline 2 & TPI & 1 & 0,8 & 1 & 1 & 0,9 \\
\hline 3 & PDL & 0,7 & 0,7 & 1 & 1 & 1 \\
\hline 4 & SF & 1 & 0,9 & 0,8 & 1 & 1 \\
\hline 5 & $A F$ & 0,9 & 0,6 & 0,5 & 0,5 & 0,5 \\
\hline 6 & CAR & 1 & 1 & 1 & 0,9 & 1 \\
\hline 7 & BRIL & 0,8 & 0,6 & 1 & 0,6 & 0,7 \\
\hline 8 & MGI & 1 & 1 & 0,7 & 0,7 & 0,7 \\
\hline 9 & ACA & 1 & 1 & 0,9 & 0,8 & 0,9 \\
\hline 10 & ABA & 1 & 0,9 & 1 & 1 & 1 \\
\hline 11 & MI & 1 & 1 & 0,9 & 0,7 & 0,6 \\
\hline 12 & FT & 0,8 & 0,8 & 1 & 1 & 1 \\
\hline 13 & AlA & 1 & 1 & 1 & 1 & 1 \\
\hline
\end{tabular}

smallest inefficiency value is PT. Askrida Insurance with a value of 0.9920 while the Islamic insurance company with the highest inefficiency value is PT. AXA Financial with an efficiency value of 0.6425 .

Based on the discussion of the results of the above research it is known that there is one Islamic Insurance company that experiences $100 \%$ efficiency, namely PT. AIA Financial. This result is in accordance with Sabiti (2017) research, where the results of his research state that PT. AIA Financial is one of the Islamic Insurance companies with $100 \%$ efficiency in 2013-2015. Furthermore, the results of research conducted by Benarda (2016) prove that PT. AIA Financial is a Islamic Insurance company with a value of $100 \%$ technical efficiency in 2011-2014. It is found that there are still many companies that experience inefficiencies, this shows that the Islamic Insurance companies in Indonesia still have considerable room for improvement. The results of this study are similar to the research conducted by Al-Amri (2015), which states that Islamic Insurance in GCC countries has been quite efficient but still needs improvement so that fund management becomes efficient. This means that Islamic Insurance companies at home and abroad still need repairs to reach the perfect optimization point. 
Factors that cause inefficiency are divided into two, namely the input and output factors. The dominant input factor causing the inefficiency of Islamic insurance companies is operating expenses and claim payments, while the output factors that cause inefficiencies are contributing factors and investment income. PT.AIA Financial stood earlier than PT. Takaful Family, so that the assets owned and the operational costs borne are higher. This can be caused by the growth of a wider range of regions. While the difference between the contributions made by the two companies is quite large, meaning that there is a different marketing effort or the value of the contribution policy. Tabarru's investments and funds obtained by the two companies are normal and in accordance with the assets of the two companies.

But if we look at the difference in claims paid by PT. AIA Financial and PT. Takaful Family has a very long distance and is inversely proportional. PT. Takaful Family makes very high claim payments, which results in companies experiencing inefficiencies. While PT. AIA Financial makes claim payments with low initial payments. After a thorough analysis of each variable, it is known that only the claim variable shows significant differences between Islamic insurance companies.

The theoretical implications of the results of this study are that efficiency at the Islamic Insurance company is not related to the assets of the Islamic Insurance company. Islamic Insurance Companies with high assets and earlier operational activities do not guarantee the level of efficiency. In this study, it is known that PT.Takaful Keluarga has assets greater than PT.Asuransi Bangun Askrida, but the level of efficiency of PT. Asuransi Bangun Askrida is better than PT.Takaful Keluarga. This research also shows that the inefficiencies experienced by Islamic Insurance companies are due to high operating expenses and the payment of claims that have not been optimal.

Efforts to increase the value of efficiency can be done with a thorough evaluation, one of them is a comparative study of the financial performance of a Islamic insurance company that has the highest and smallest qualification values. Then identify thoroughly on each variable. Increasing the efficiency value of Islamic insurance companies in Indonesia can also use the CRS, IRS and DRS classification methods.

Islamic Insurance Companies must review the claim payment policy and decision to invest. In addition, the contribution has not been maximized so that Islamic Insurance companies must continue to issue innovations in terms of marketing Sharia Insurance products. 


\section{Conclusion}

Based on the results of the study, the efficiency of Islamic insurance companies in Indonesia has not achieved efficiency in the 2012-2016 period. The dominant input factor causing inefficiency of Islamic insurance companies is the factor of operating expenses and claim payments, while the output factor that causes inefficiency is the factor of contribution and investment income. The efforts that can be taken by the company are policies and marketing that will support the growth of productivity income of Islamic insurance companies.

[1] Abduh, M. (2012). The Performance of Insurance Industry in Malaysia: Islamic vis-avis Conventional Insurance. Journal of Islamic Banking and Finance Volume 29. No. 4 Oct - Dec. 2012, 40.

[2] Al-Amri, K. (2015). Takaful insurance efficiency in the GCC countries. Humanomics Vol. 31 No. 3, 2015, pp. 344-353, 344-353.

[3] Benarda. (2016). Tingkat Efisiensi Industri Asuransi Syariah menggunakan pendekatan two stage data envelopment analysis. Jurnal Aplikasi Bisnis dan Manajemen, Vol. 2 No. 1 Januari 2016, 64-72.

[4] Berlian, M. I. (2017). Pengelolaan Dana Tabarru' Asuransi Jiwa Syariah. Medina-Te, Vol.16, No.1, Juni 2017, 25.

[5] Faozi, M. M. (2016). Manajemen Dana Tabarru' Pada Asuransi Takaful Cabang Cirebon. Jurnal Al-Mustashfa Vol.4 No.2 , 153.

[6] Farrell, M. J. (1957). The Measurement of Productive Efficiency. Journal of the Royal Satistical Society, 253.

[7] Faruk, M. O., \& Rahaman, A. (2015). Measuring Efficiency of Conventional Life Insurance Companies in Bangladesh and Takaful Life Insurance Companies in Malaysia: A Non-Parametric Approach. Management Studies and Economic Systems (MSES), 2 (2), 129-144, Autumn 2015, 130-144.

[8] Hidayat, R. (2014). Efisiensi Perbankan Syariah (Teori dan Praktik). Bekasi: Gramata Publishing.

[9] Janjua, P. Z., \& Akmal, M. (2015). A Comparative Analysis Of Economic Efficiency Of Conventional And Islamic Insurance Industry In Pakistan. Pakistan Business Review April 2015, 21-44.

[10] Juliana, Firmansyah, \& Pratama, B. (2016). Telaah Pemikiran Ekonomi Islam : Yahya Bin Adam Al-Qarashi ( \pm 140 H/755 M - 203 H/818 M). Ekspansi Vol. 8, No. 1 (Mei 
2016), Hal. 77 - 85.

[11] Khan, A. (2014). Efficiency Measure Of Insurance V/S Tak Ful Firms Using Dea Approach: A Case Of Pakistan. Islamic Economic Studies Vol. 22, No. 1, May, 2014, 139-158.

[12] Kurnia, N. (2015). Islamic Finance Outlook. Rawa Pening: Karim Consulting Indonesia.

[13] Maksum, M. (2011). Pertumbuhan Asuransi Syariah Di Indonesia Dan Di Dunia. Allqtishad: Vol. lii, No. 1, Januari 2011, 37-47.

[14] Nahar, H. S. (2015). Insurance Vs Takaful: Identical Sides Of A Coin? Journal Of Financial Reporting And Accounting Vol. 13 Issue: 2, pp.247-266.

[15] OJK. (2017). Statistik IKNB Syariah. Jakarta: OJK.

[16] Rahman, M. A. (2013). Comparative Study on the Efficiency of Bangladeshi Conventional and Islamic Life Insurance Industry: A Non-Parametric Approach. Asian Business Review, Volume 2, Number 3/2013 (Issue 5) ISSN 2305-8730.

[17] Saad, N. M. (2011). Efficiency of Life Insurance Companies in Malaysia and Brunei: A Comparative Analysis. International Journal of Humanities and Social Science, Vol. 1 No. 3; March 2011, 111-122.

[18] Sabiti. (2017). Efisiensi Asuransi Syariah di Indonesia dengan pendekatan Data Envelopment Analysis. Jurnal Al-Muzara'ah Vol.5, No.1, 2017, ISSN p: 23376333;e:2355-4363, 69-87.

[19] Shafique, M. N. (2015). A Comparative Study Of The Efficiency Of Takaful And Conventional Insurance In Pakistan. International Journal of Accounting Research Vol. 2, No. 5, 2015.

[20] Sherif, M., \& Shaairi, N. A. (2013). Determinants of demand on family Takaful in Malaysia. Journal of Islamic Accounting and Business Research Vol. 4 No. 1, 2013, 26-50 Emerald Group Publishing Limited 1759-0817 DOI 10.1108/17590811311314276.

[21] Tasman, A., \& Aima, M. H. (2013). Ekonomi Manajerial Dengan Pendekatan matematis. Depok: PT. Rajagrafindo Persasa.

[22] Tuffahati, M. \&. (2016). Pengukuran Efisiensi Asuransi Syariah Dengan Data Envelopment Analysis (Dea). Jurnal Akuntansi Dan Keuangan Islam Vol. 4, No. 1 (2016).

[23] Wilko, k. (2017). Asuransi Takaful Umum Tutup, Ini Yang Harus Diperhatikan Asuransi Syariah lainnya. Jakarta: BESConsultant(insurance, Risk management, Finance And Actuary). 